\title{
Influence of protein supplementation of primiparous ewes during gestation on birth weight and perinatal mortality of lambs in the sudano-sahelian Cameroon
}

\author{
A Njoya, AC Ngo Tama, ND Awa \\ Animal and Veterinary Research Institute (IRZV) and The Small Ruminant Regional \\ Research Project, PO Box 1073, Garoua, Cameroon
}

More evidence indicates that the body condition score is a reliable method in assessing the body reserves and the nutritional status of breeding ewes (Dedieu et al, 1988, INRA Prod Anim, 2, 79-88). Nutritional stresses during 6 to 9 months of the dry season, parasites and pneumonia during the cold months of the year are major contributing factors to high mortality of sheep in sahelian zones (Njoya and Awa, Unpublished). The objective of this study was to evaluate the influence of a protein supplement during gestation of primiparous ewes on birth weight (BWT) and perinatal mortality of lambs (PNM).

164 ewes from a previous experiment aged 12 to 15 months, were maintained in two treatments : 89 supplemented ewes (Suppl), and 75 with no supplement (control). Flocks were herded separately on natural pastures. To reduce the effects of herders and paddocks from the analysis, flocks were rotating between herders and paddocks every month. From December 1993, the supplemented ewes were group fed $200 \mathrm{~g}$ cottonseed meal $(40.8 \%$ crude protein) per head per day. Body condition score (BCS) was determined on a 4 scales notation. Breeding was synchronised using Chrono-gestr (INRA method) in January 1994 and lambing occurred mostly in June and some in July. PNM was calculated as the number of stillbirths and lambs born alive, but died before 7 days of age, over the total number of lambs born.

The supplemented ewes were heavier and their BCS was higher at lambing compared with the control $(P<0.01)$. However, with the nutritional hardship during the dry season and the need for maintaining gestation to term, both groups lost BCS, but the lost was minimal for the supplemented group compared with the control. Supplementation significantly increased the fertility rate (FERT) of the ewes $(P<0.05)$ and the BWT of the lambs $(P<0.01)$. BWT was correlated with live weight of ewes (LWT) at lambing $(r=0.40 ; P<0.01)$. Protein supplementation of the dams significantly decreased PNM of the lambs $(P<0.01)$. There was a significant difference in BWT between lambs that died and those that survived $(P<0.01)$. The mean BWT of the 24 lambs that died was $1.20 \pm 0.47 \mathrm{~kg}( \pm \mathrm{SD}$ ) compared with $2.15 \pm 0.61 \mathrm{~kg}$ for the 136 that survived. BWT decreased $(P<0.01)$ and $P N M$ increased $(P<0.05)$ with multiple births. BWT was $2.30 \pm$ $0.67 \mathrm{~kg}, 1.81 \pm 0.50 \mathrm{~kg}$, and $1.11 \pm 0.33 \mathrm{~kg}$ respectively for single, double and triple birth lambs. PNM was 7.6 p.100, 19.1 p.100 and 46.2 p.100 in the same order. 87.5 p.100 of PNM was attributed to lower BWT and weakness, preventing standing and suckling. BWT of lambs was the major factor in their survival and was improved with protein supplementation of dams during gestation which was in accordance with findings of Stephenson and Bird (1992, Aust J Exper Agric, 32, 157-162). The cost of protein supplementation was economically justified in this study.

In conclusion, when the nutrition from natural pasture was inadequate, supplementing primiparous ewes with $200 \mathrm{~g}$ of cottonseed meal/animal/day prevented a critical loss of BCS and permitted a significant increase in LWT during gestation. This resulted in an increase in lamb BWT of $0.5 \mathrm{~kg}$ and a reduction in PNM by more than 50 p. 100 .

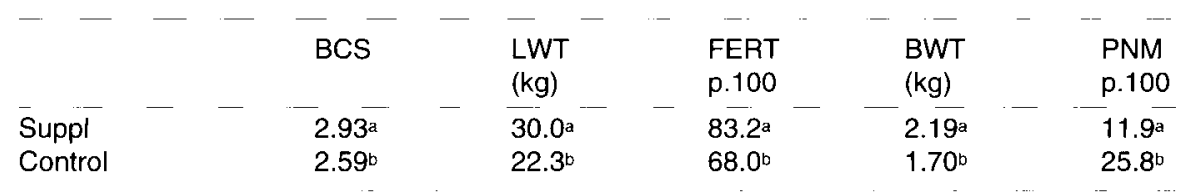

